\title{
Genetic Selection for Health Traits Using Producer-Recorded Data. II. Genetic Correlations, Disease Probabilities, and Relationships with Existing Traits
}

\author{
N. R. Zwald, ${ }^{1}$ K. A. Weigel, ${ }^{1}$ Y. M. Chang, ${ }^{1}$ R. D. Welper,${ }^{2}$ and J. S. Clay ${ }^{3}$ \\ ${ }^{1}$ University of Wisconsin-Madison, Department of Dairy Science, Madison, 53706 \\ ${ }^{2}$ Alta Genetics, Inc., Watertown, WI 53094 \\ ${ }^{3}$ Dairy Records Management Systems, Raleigh, NC 27695
}

\begin{abstract}
The objectives of this study were to calculate genetic correlations between health traits that were recorded in on-farm herd management software programs and to assess relationships between these traits and other traits that are routinely evaluated in US dairy sires. Data consisted of 272,576 lactation incidence records for displaced abomasum (DA), ketosis (KET), mastitis (MAST), lameness (LAME), cystic ovaries (CYST), and metritis (MET) from 161,622 cows in 646 herds. These data were collected between January 1, 2001 and December 31, 2003 in herds using the Dairy Comp 305, DHI-Plus, or PCDART herd management software programs. Binary incidence data for all disorders were analyzed simultaneously using a multiple-trait threshold sire model that included random sire and herd-yearseason of calving effects. Although data from multiple lactations were available for some animals, our genetic analysis included only first parity records due to concerns about selection bias and improper modeling of the covariance structure. Heritability estimates for the presence or absence of each disorder during first lactation were 0.14 for DA, 0.06 for KET, 0.09 for MAST, 0.03 for LAME, 0.04 for CYST, and 0.06 for MET. Estimated genetic correlations were 0.45 between DA and KET, 0.42 between KET and CYST, 0.20 between MAST and LAME, 0.19 between KET and LAME, 0.17 between DA and CYST, 0.17 between KET and LAME, 0.17 between KET and MET, and 0.16 between LAME and CYST. All other correlations were negligible. Correlations between predicted transmitting abilities for the aforementioned health traits and existing production, type, and fitness traits were low, though it must be noted that these estimates may have been biased by low reliability of the health trait evaluations. Based on results of this study, it appears that genetic selection
\end{abstract}

Received July 13, 2004.

Accepted September 10, 2004.

Corresponding author: Kent Weigel; e-mail: kweigel@wisc.edu. for health disorders recorded in on-farm software programs can be effective. These traits can be incorporated into selection indices directly, or they can be combined into composite traits, such as "reproductive disorders", "metabolic disorders", or "early lactation disorders".

(Key words: health traits, metabolic disorders, genetic correlations, disease incidence)

Abbreviation key: CYST = cystic ovaries, DA = displaced abomasum, DPR = daughter pregnancy rate, DRMS = Dairy Records Management Systems, KET = ketosis, LAME = lameness, LIR = lactation incidence rate, $\mathbf{M A S T}=$ mastitis, $\mathbf{M E T}=$ metritis, $\mathbf{P L}=$ length of productive life.

\section{INTRODUCTION}

Genetic selection for disease resistance in dairy cattle has been discussed for many years, but data regarding disease occurrences have not been collected routinely on US dairy farms. Before 1994, no health or fitness traits were included in the national breeding goal (www.aipl.arsusda.gov). This strategy led to significant genetic progress for production and conformation traits, but because of the antagonistic relationship between milk production and disease resistance, some health traits have deteriorated (Rauw et al., 1998). Since 1994, selection has proceeded using indirect indicators that are routinely measured within the DHI system, such as SCS and length of productive life (PL).

Beaudeau et al. (1999) reported that metabolic disorders seem to have a smaller impact on the likelihood of culling than poor milk production or poor reproductive performance. They note, however, that a metabolic disorder may not cause culling immediately; it may decrease the animal's milk production or impair its reproductive performance, such that the animal is culled at a later date. Pryce and Brotherstone (1999) reported a significant relationship between likelihood of culling and calving interval and clinical mastitis (MAST); estimated genetic correlations were 0.44 and 0.22 respectively. 
In Danish Holsteins, Sander-Nielsen et al. (1999) reported low heritability estimates for clinical MAST (0.05), metabolic disorders (0.01), and feet and leg disorders (0.01). However, they estimated relatively high genetic correlations between longevity and both MAST (0.52) and metabolic disorders (0.43). Sander-Nielsen et al. (1999) also noted modest genetic correlations between longevity and both feet and leg diseases (0.18) and reproductive disorders (0.17). Other studies have shown that genetic and phenotypic correlations between various metabolic diseases, such as displaced abomasum (DA) and ketosis (KET) are large and positive (Uribe et al., 1995; Shaver, 1997).

The present study focuses on data regarding the incidence of health disorders on commercial farms, as collected electronically from on-farm herd management software programs. On-farm records provide the only opportunity for direct selection for disease resistance in US dairy cattle, because recording of health disorders is not mandatory, and many farm employees routinely diagnose and treat diseases without the involvement of a veterinarian. Despite the promise of on-farm health data, research regarding the usefulness of such data for genetic evaluation purposes is lacking, most likely because recording practices are not standardized across farms, and mechanisms for routine retrieval of such data do not exist.

The objectives of this study were: 1) to compute genetic correlations between health traits commonly recorded in on-farm herd management software programs; 2) to assess relationships between these traits and other traits that are routinely evaluated in US dairy sires, and 3) to examine alternatives for including these traits in a genetic selection program.

\section{MATERIALS AND METHODS}

Data corresponding to health disorders that occurred between January 1, 2001 and December 31, 2003 (in cows that calved between January 1, 2001 and August 31, 2003) were available for 2 groups of herds: Alta Genetics (Watertown, WI) Advantage Progeny Test Program cooperators and Dairy Records Management Systems (DRMS) (Raleigh, NC) customers. Data from the former were copied directly from on-farm computers by Alta Genetics employees in herds that used the Dairy Comp 305 (Valley Ag Software, Tulare, CA), PCDART (DRMS, Raleigh, NC), or DHI-Plus (DHI-Provo, Provo, UT) software programs. Data from herds that used PCDART and elected to provide access to the health records of their cattle were uploaded electronically to DRMS monthly. Incidence data corresponding to DA, KET, MAST, lameness (LAME), cystic ovaries (CYST), and metritis (MET) were available for 272,576 lactation records from 161,622 cows in 646 herds.

Two separate analyses were carried out, one that used all available lactation records, and one that consisted of first parity records only. Although the former included much more data, it was susceptible to selection bias (because some animals lacked first parity records) and improper modeling of the covariance structure (because repeated records on the same animal were not independent). Therefore, only results of the first parity analysis are reported. Additional details regarding data collection and editing, as well as a summary of the number of usable herds, lactation records, cows, and sires is provided in Zwald et al. (2004). Likewise, details regarding single-trait analyses of these disease incidence data are provided by Zwald et al. (2004).

In the present study, incidence data (presence or absence during the first lactation) for the 6 aforementioned health disorders were analyzed simultaneously using a multiple-trait threshold sire model that accounted for the binary $(0,1)$ nature of the data. Similar methodology has been used for analyzing clinical MAST data from various periods of the lactation (e.g., Heringstad et al., 2003; Chang et al., accepted). In matrix notation, the model for liability to disease in first lactation was as follows:

$$
\lambda=\mathbf{Z}_{\mathbf{h}} \mathbf{h}+\mathbf{Z}_{\mathbf{s}} \mathbf{s}+\mathbf{e}
$$

where $\lambda=$ a vector of unobserved liabilities to a particular disease, $\mathbf{h}=$ vector of random herd-year-season effects (Jan-June, July-Dec), $\mathbf{s}=$ vector of random sire effects, distributed as $\mathbf{N}(\mathbf{0}, \mathbf{A} \otimes \mathbf{V s})$, where $\mathbf{A}$ is the relationship matrix between sires, and Vs is the genetic covariance matrix between the 6 health disorders considered in this study, $\mathbf{e}=$ vector of random residual effects, distributed as $\mathrm{N}(\mathbf{0}, \mathbf{I} \otimes \mathbf{V e})$, where $\mathbf{I}$ is an identity matrix and $\boldsymbol{V e}$ is the residual correlation matrix between the 6 health disorders considered in this study (i.e., residual variances were constrained to unity for computational reasons), and $\mathbf{Z}_{\mathbf{h}}$, and $\mathbf{Z}_{\mathbf{s}}=$ corresponding incidence matrices.

Posterior means of sire transmitting abilities were transformed from the underlying liability scale to probability of disease using the following function:

$$
\mathrm{P}_{\mathrm{ij}}=\Phi\left(\mu_{\mathrm{i}}+\hat{\mathrm{s}}_{\mathrm{ij}}\right)
$$

where $\mathrm{P}_{\mathrm{ij}}=$ probability of disease $\mathrm{i}$ for daughters of sire j, $\Phi=$ standard normal cumulative density function, $\mu=$ probit function corresponding to the mean liability of disease $\mathrm{i}$, and $\hat{\mathrm{s}}_{\mathrm{ij}}=$ posterior mean of liability to disease $\mathrm{i}$ for daughters of sire $\mathrm{j}$. 
Table 1. Number of herds (above diagonal) and cows (below diagonal) that had usable records for each combination of health disorders considered in the present study.

\begin{tabular}{lcccccc}
\hline & $\begin{array}{c}\text { Displaced } \\
\text { abomasum }\end{array}$ & Ketosis & Mastitis & Lameness & $\begin{array}{l}\text { Cystic } \\
\text { ovaries }\end{array}$ & Metritis \\
\hline Displaced abomasum & & 185 & 232 & 136 & 179 & 253 \\
Ketosis & 73,831 & & 217 & 124 & 150 & 230 \\
Mastitis & 95,748 & 80,044 & & 192 & 208 & 338 \\
Lameness & 57,743 & 43,863 & 75,005 & & 115 & 189 \\
Cystic ovaries & 62,782 & 45,535 & 70,966 & 46,708 & & 256 \\
Metritis & 106,190 & 87,900 & 132,837 & 79,548 & 87,459 & \\
\hline
\end{tabular}

\section{RESULTS AND DISCUSSION}

As noted in Zwald et al. (2004), herds were more likely to consistently record DA, MAST, and MET than other diseases, and the most consistent recording practices were observed for DA, most likely due to the need for veterinary assistance and the high cost of the disorder (Guard, 1998). On the other hand, herds were least likely to record lameness in a consistent, complete manner. Overall, consistency of data recording should be improved, such that fewer records will be discarded during the editing process and genetic evaluations of individual sires will be based on larger progeny groups.

Although it would have been ideal to include those herds that recorded all 6 health disorders consistently, this was not possible. Many herds provided useful data for only 1 or 2 diseases, as noted in Table 1, and all other traits (diseases) were considered missing for these herds. This reduced the number of links or connections between herds for certain pairs of disorders. Overall, only 43 herds reported useful data for all 6 disorders examined in this study, so the majority of animals had missing records for one or more individual diseases. In some herds, recording practices were somewhat ambiguous, and specific diseases could not be distinguished. For example, an abbreviation such as "PEN" could mean that the cow received penicillin, or it could mean that the cow was moved to a different pen. The challenges regarding data recording and standardization are further discussed by Zwald et al. (2004).

In the multiple-trait threshold model analysis, heritability estimates were 0.14 for DA, 0.06 for KET, 0.09 for MAST, 0.04 for LAME, 0.04 for CYST, and 0.06 for MET, as noted in Table 2. Posterior standard deviations of these estimates ranged from 0.01 to 0.03 , indicating that all estimates were significantly greater than zero. In other words, all 6 of these farmer-recorded health disorders seem to have a genetic component, and genetic selection based on such data may help reduce the incidence of these diseases. As shown in Table 2, estimated genetic correlations among the aforementioned health disorders ranged from -0.01 (between MAST and MET) to 0.45 (between DA and KET). Other notable estimates were 0.42 between KET and CYST, 0.20 between MAST and LAME, 0.19 between KET and LAME, 0.17 between DA and CYST, 0.17 between KET and LAME, 0.17 between KET and MET, and 0.16 between LAME and CYST. Positive genetic relationships between these traits seem to indicate that daughters of certain sires tend to be susceptible to all health disorders, perhaps because they lack an adequate general immune response, or because they experience extreme negative energy balance in early lactation. Because connections between herds were limited for certain pairs of traits, posterior standard deviations were relatively large, ranging from 0.14 to 0.27 . For example, 212 and 250 herds reported usable data for KET and LAME, respectively, but only 124 of these herds provided useful data for both disorders.

In the past half-century, the majority of selection pressure in the US has focused on production and conformation traits. However, several fitness traits have been introduced within the past decade, including PL, SCS, daughter pregnancy rate (DPR), and daughter calving ease. Therefore, the genetic relationships between these fitness traits and the disease incidence traits considered in the present study are of interest.

Table 2. Estimated heritability of each health disorder (on diagonal) and estimated genetic correlations between health disorders (above diagonal).

\begin{tabular}{|c|c|c|c|c|c|c|}
\hline & $\begin{array}{l}\text { Displaced } \\
\text { abomasum }\end{array}$ & Ketosis & Mastitis & Lameness & $\begin{array}{l}\text { Cystic } \\
\text { ovaries }\end{array}$ & Metritis \\
\hline Displaced abomasum & $0.14 \pm 0.03$ & $0.45 \pm 0.16$ & $0.08 \pm 0.17$ & $0.07 \pm 0.14$ & $0.17 \pm 0.27$ & $0.08 \pm 0.14$ \\
\hline Ketosis & & $0.06 \pm 0.02$ & $0.17 \pm 0.21$ & $0.19 \pm 0.21$ & $0.42 \pm 0.23$ & $0.17 \pm 0.20$ \\
\hline Lameness & & & & $0.04 \pm 0.01$ & $0.16 \pm 0.27$ & $0.07 \pm 0.20$ \\
\hline Cystic ovaries & & & & & $0.04 \pm 0.01$ & $0.03 \pm 0.26$ \\
\hline Metritis & & & & & & $0.06 \pm 0.01$ \\
\hline
\end{tabular}


Table 3. Product-moment correlations between PTA for probability of disease occurrence and PTA for production, type, and other traits routinely evaluated by the USDA Animal Improvement Programs Laboratory (Beltsville, MD) and the Holstein Association USA (Brattleboro, VT).

\begin{tabular}{|c|c|c|c|c|c|c|}
\hline \multirow[b]{2}{*}{ PTA } & \multicolumn{6}{|c|}{ PTA for probability of disease } \\
\hline & $\begin{array}{l}\text { Displaced } \\
\text { abomasum }\end{array}$ & Ketosis & Mastitis & Lameness & $\begin{array}{l}\text { Cystic } \\
\text { ovaries }\end{array}$ & Metritis \\
\hline Milk & 0.09 & 0.12 & 0.09 & 0.02 & 0.10 & -0.05 \\
\hline Fat $\%$ & 0.02 & 0.06 & 0.03 & -0.06 & 0.00 & -0.03 \\
\hline Protein \% & 0.04 & 0.09 & 0.12 & -0.02 & -0.03 & 0.07 \\
\hline Somatic cell score & -0.05 & 0.03 & 0.23 & 0.02 & 0.01 & -0.03 \\
\hline Productive life & -0.14 & -0.10 & -0.14 & -0.08 & -0.02 & -0.14 \\
\hline Daughter pregnancy rate & -0.10 & -0.10 & -0.11 & -0.02 & -0.09 & -0.06 \\
\hline Daughter calving ease & 0.04 & 0.01 & -0.01 & -0.04 & -0.02 & 0.04 \\
\hline Stature & 0.08 & 0.03 & 0.02 & -0.05 & 0.01 & 0.03 \\
\hline Strength & 0.11 & 0.03 & 0.07 & -0.04 & 0.03 & 0.00 \\
\hline Body depth & 0.11 & 0.06 & 0.07 & -0.05 & 0.03 & 0.01 \\
\hline Dairy form & 0.10 & 0.13 & 0.04 & -0.05 & 0.08 & 0.02 \\
\hline Rump angle & 0.05 & 0.05 & -0.04 & -0.05 & 0.01 & -0.05 \\
\hline Thurl width & 0.06 & 0.06 & 0.03 & 0.01 & 0.05 & -0.01 \\
\hline Rear legs - side view & 0.01 & -0.03 & -0.06 & 0.01 & 0.01 & 0.03 \\
\hline Rear legs - rear view & 0.05 & 0.05 & 0.06 & -0.03 & -0.03 & 0.07 \\
\hline Foot angle & 0.01 & -0.04 & -0.04 & -0.03 & -0.08 & 0.08 \\
\hline Fore udder attachment & 0.05 & 0.02 & -0.07 & 0.02 & 0.08 & -0.03 \\
\hline Rear udder height & 0.13 & 0.12 & -0.07 & -0.02 & 0.06 & -0.07 \\
\hline Rear udder width & 0.10 & 0.13 & -0.12 & 0.01 & 0.09 & -0.13 \\
\hline Udder cleft & 0.09 & 0.05 & -0.12 & -0.02 & 0.04 & -0.02 \\
\hline Udder depth & 0.03 & -0.06 & -0.20 & 0.01 & 0.04 & 0.04 \\
\hline Front teat placement & 0.05 & 0.02 & -0.06 & 0.04 & 0.07 & -0.05 \\
\hline Teat length & -0.02 & 0.00 & 0.05 & 0.04 & 0.01 & 0.05 \\
\hline
\end{tabular}

Table 3 shows product-moment correlations between PTA for disease incidence traits from the present study and PTA for production, type, and fitness traits from the February, 2004 USDA Animal Improvement Programs Laboratory (Beltsville, MD) and the Holstein Association USA (Brattleboro, VT) sire summaries. Because of the low reliability of sire PTA for the 6 disease traits considered herein, correlations shown in Table 3 tend to underestimate the true genetic correlations between these traits, and attention should focus on the direction of these relationships, rather than the magnitude.

Correlations between disease traits and PTA milk were positive for all disorders except metritis, and this may reflect an antagonistic relationship between milk yield and disease in dairy cattle. The estimated correlation between PTA for SCS and PTA for MAST was 0.31, indicating that selection for improved SCS will decrease the incidence of MAST. Many farms seek to reduce the incidence of clinical MAST and maximize SCS premiums, so incorporation of both traits into genetic selection programs seems appropriate.

A negative association was found between all 6 disease traits and both PL and DPR, indicating that the incidence of disease seems to hamper reproductive performance and impair cow survival, as suggested by previous researchers (Guard, 1998; Rauw et al., 1998; Sander-Nielsen et al., 1999). Antagonistic relationships were also noted between metabolic disorders (DA, KET) and conformation traits, such as frame and rear udder height. A similar, negative relationship between metabolic disease and body size was reported in the Minnesota body size selection project (Jones et al., 1994; Hansen et al., 1999).

Sire PTA for clinical MAST were positively correlated with PTA for all udder traits, most notably udder depth $(-0.20)$, indicating that selection for desirable udder conformation is likely to reduce mastitis incidence. This result was previously reported by Rogers et al. (1991, 1999), and it most likely occurs because cows with correct udder conformation stay cleaner, avoid injury, and milk out more completely.

The availability of incidence data for common dairy disorders necessitates the development of a coherent, user-friendly approach for reporting sire evaluations and incorporating these into genetic selection programs. Given a multiple-trait genetic evaluation model, such as the model presented herein, one can compute the individual probability of each disease among progeny of a particular sire or the joint probability of several diseases among progeny of this sire.

In the present study, probabilities of disease were expressed in 6 different ways: 1) probability of a metabolic disorder (DA or KET); 2) probability of an early lactation disorder (DA, KET, or MET); 3) probability of a reproductive disorder (CYST or MET); 4) probability of any disorder except mastitis (DA, KET, LAME, 
CYST, or MET); 5) probability of any disorder (DA, KET, MAST, LAME, CYST, or MET), and 6) expected disease cost in first lactation. The latter measure was calculated in the following manner. Guard (1998) estimated the financial loss associated with an episode of DA, KET, LAME, or MET, including labor, veterinary treatment, discarded milk, reduced milk production, and increased risk of culling, as $\$ 340, \$ 145, \$ 285$, or $\$ 300$, respectively. In a similar manner, Jasper et al. (1982) estimated the financial loss associated with a case of clinical MAST to be $\$ 175$. Lastly, Bartlett et al. (1986) estimated the financial loss associated with a case of CYST to be $\$ 170$. One might argue that the cost of CYST has decreased over time because of the availability of ultrasound technology and inexpensive hormonal synchronization programs. Furthermore, cystic ovaries may not necessarily be a good indicator of a cow's ovulatory status (anovular vs. ovular), and direct genetic evaluation of ovulatory status may be preferred, if possible. Lastly, it is important to note that reduced milk production because of disease is already reflected in the PTA milk of each sire, and use of the aforementioned economic values may lead to overestimation of the total financial impact of these diseases if PTA milk is also included in the merit index. Therefore, these calculations should be viewed as an illustration of a potential method to present sire PTA for disease traits, rather than concise estimates of the economic impact of animal disease.

In the present study, the probability of disease among daughters of each sire was multiplied by the corresponding cost of a clinical episode, and these were summed across disorders for a given sire. In this manner, the expected cost of disease in first lactation was computed. For example, for a typical sire with disease probabilities of 0.033 for DA, 0.100 for KET, 0.186 for MAST, 0.196 for LAME, 0.065 for CYST, and 0.096 for MET, the expected cost of disease would be calculated as:

$$
\begin{gathered}
(0.033 \times \$ 340)+(0.10 \times \$ 145)+(0.186 \times \$ 175) \\
+(0.196 \times \$ 285)+(0.096 \times \$ 300) \\
+(0.065 \times \$ 170)=\$ 153.80
\end{gathered}
$$

Following this approach, all sires would receive an "expected cost of daughter disease in first parity" which would deviate from an average of $\$ 153.80$, and sires with lower than expected disease costs would be preferred. In practice, it may be more desirable to use deviations from breed average, rather than actual probabilities of disease, so that diseases with higher lactation incidence rates (LIR) are not weighted more heavily. A strategy of this type could be used to incorporate clinical disease traits into the USDA Animal Improve-

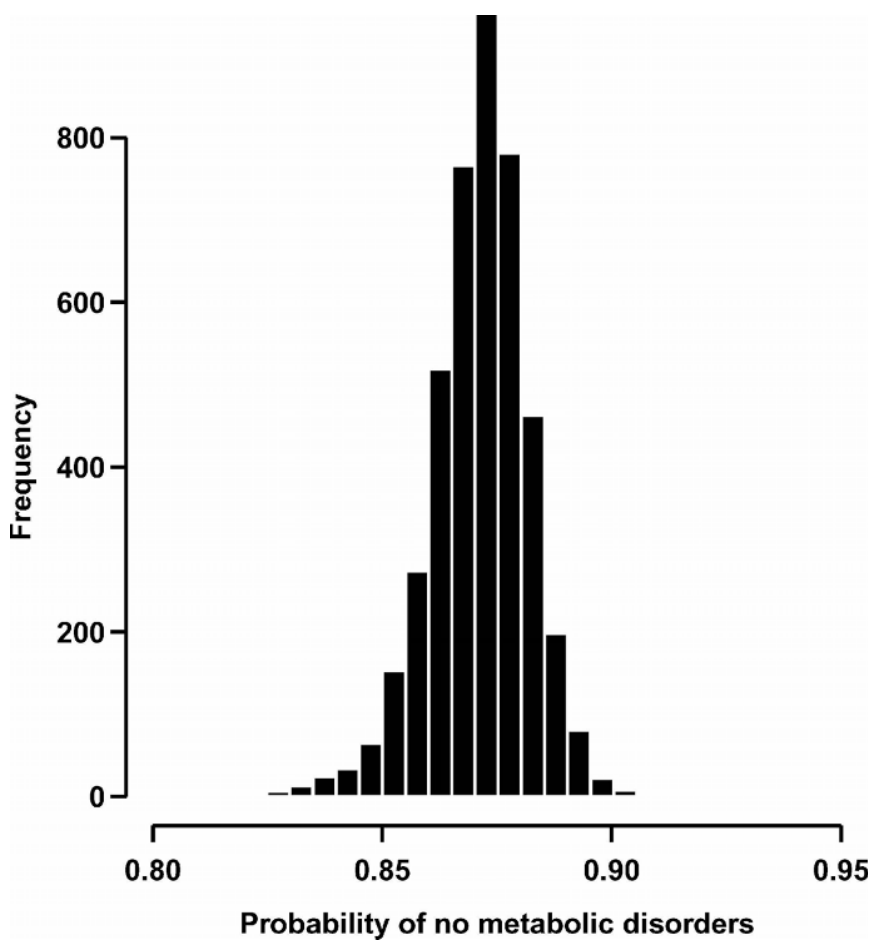

Figure 1. Frequency distribution of PTA of Holstein sires for probability resistance to metabolic disorders.

ment Programs Lifetime Net Merit index (www.aipl.arsusda.gov). Obviously, the costs of these health disorders vary between farms and between research studies, and accurate and robust estimation of such costs is critical.

Frequency distributions of sire PTA for each of the 6 disease composites are shown in Figures 1 through 6. Each reflects the probability of disease or expected cost of disease among first-lactation daughters. As shown in Figure 1, range in sire PTA for "probability of no metabolic disorder" in first-lactation daughters ranged from 0.82 to 0.91 . Likewise, as shown in Figure 2 , the "probability of no early lactation disorder" in first parity ranged from 0.62 to 0.76 . The "probability of no reproductive disorder" in first parity ranged from 0.64 to 0.81 , as shown in Figure 3, and the "probability of no disease other than mastitis" ranged from 0.52 to 0.67, as shown in Figure 4. Lastly, the "probability of no disease" in first lactation, ranged from 0.34 to 0.53 , as shown in Figure 5, and the "expected cost of disease" in first lactation ranged from $\$ 128$ to $\$ 169$ (Figure 6).

Estimated product-moment correlations between these PTA for these disease composites and PTA for production, conformation, and fitness traits are shown in Table 4. Again, keep in mind that correlations between sire PTA underestimate true genetic correlations unless reliabilities approach unity. An antagonistic re- 


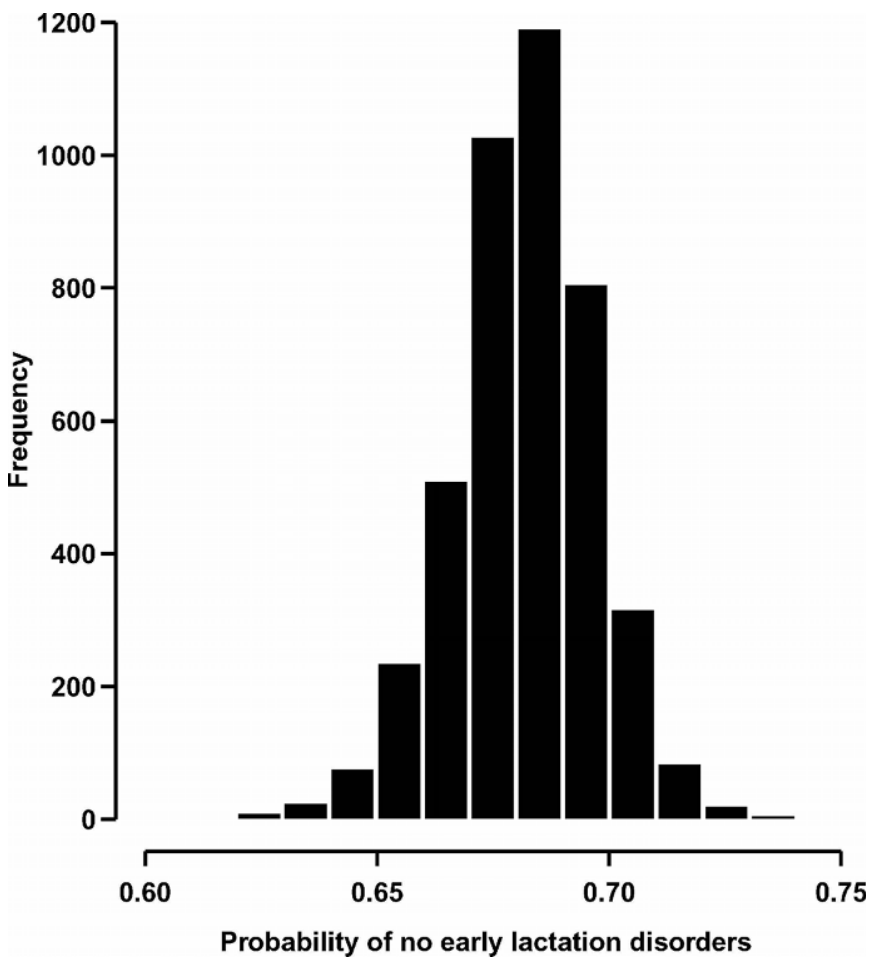

Figure 2. Frequency distribution of PTA of Holstein sires for probability of resistance to early lactation disorders.

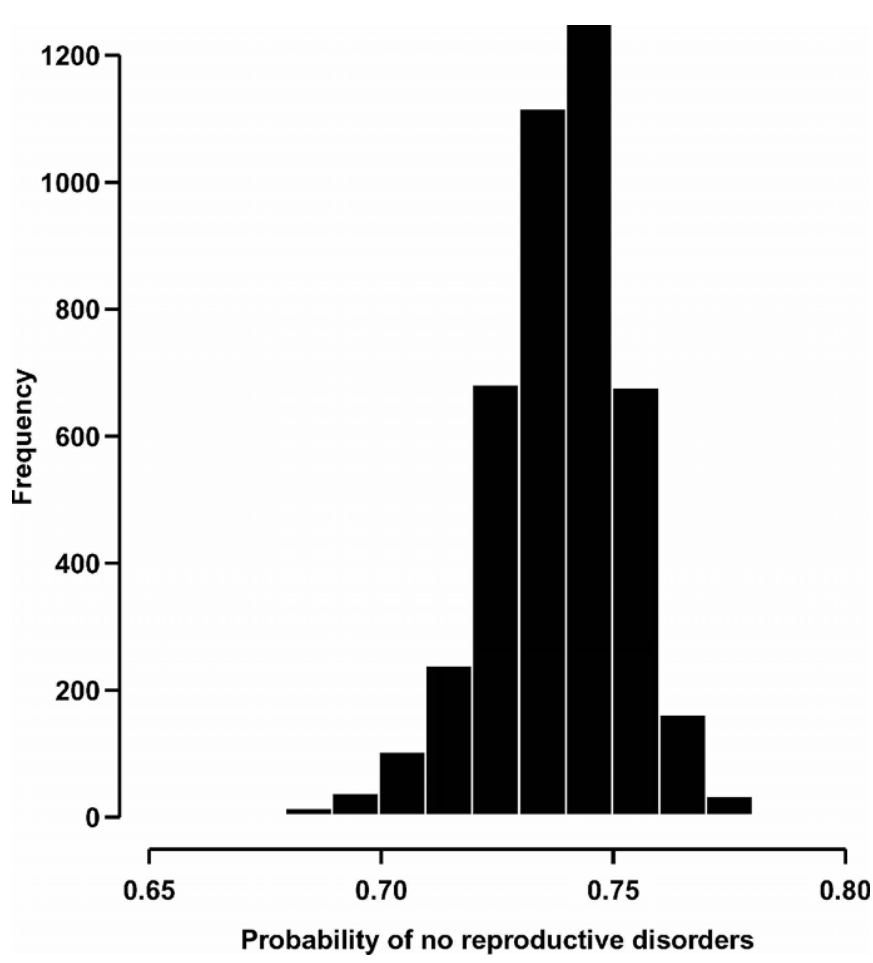

Figure 3. Frequency distribution of PTA of Holstein sires for probability of resistance to reproductive disorders.

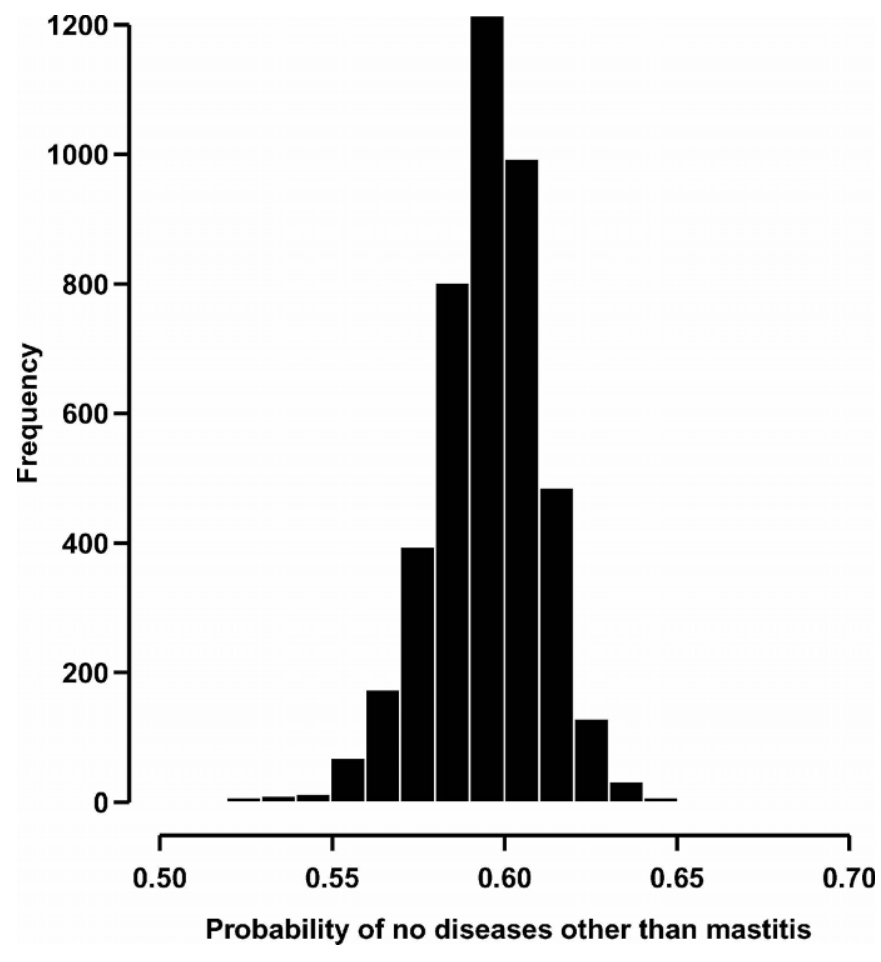

Figure 4. Frequency distribution of PTA of Holstein sires for probability of resistance to all disorders except mastitis.

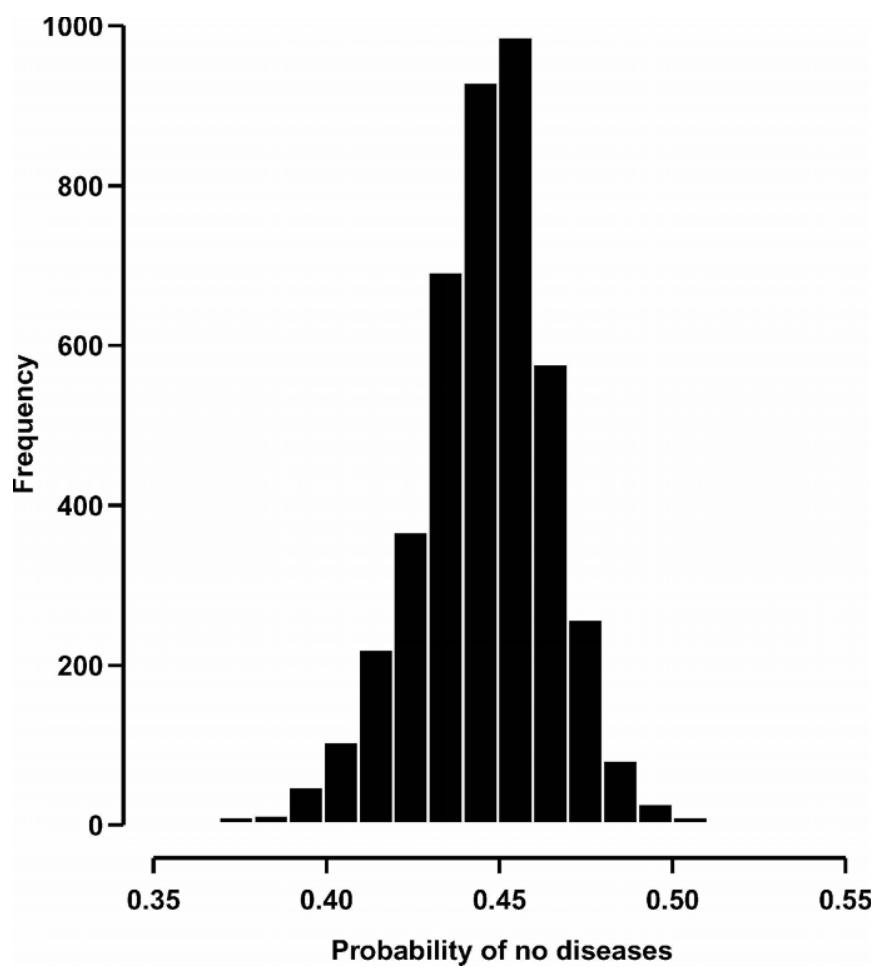

Figure 5. Frequency distribution of PTA of Holstein sires for probability of resistance to all health disorders. 


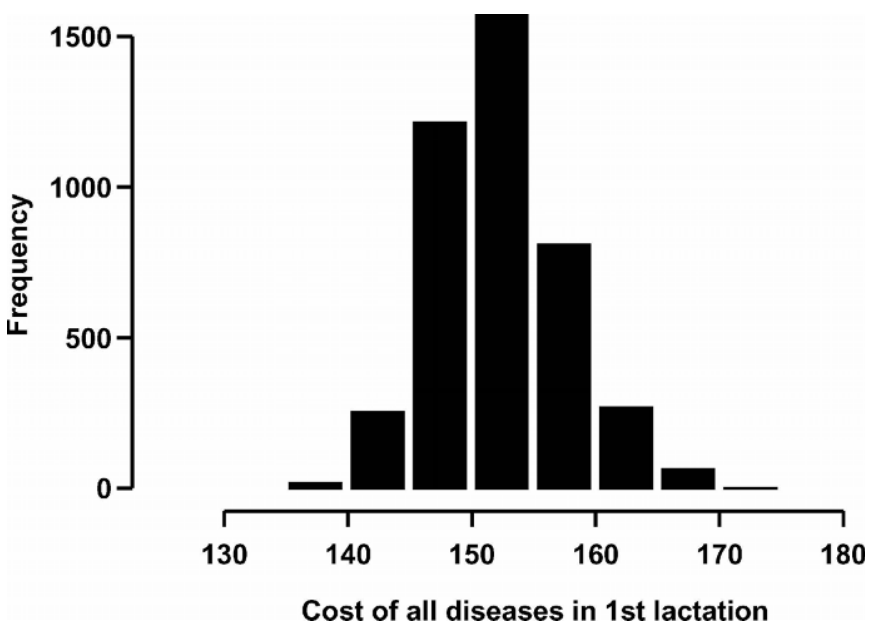

Figure 6. Frequency distribution of expected disease costs in first lactation for Holstein sires in this study.

lationship was observed between milk production and the probability of no metabolic disorders, as expected. Correlations of PL and DPR with probabilities of no disease were positive, indicating that selection for disease resistance would tend to improve these traits as well. Dairy form, which has been implicated as a potential indicator of disease susceptibility by several authors (e.g., Dechow, 2003), was negatively correlated with all measures of disease resistance. Furthermore, body size traits showed a slightly negative relationship with disease resistance, confirming the findings of Hansen et al. (1999). Correlations between disease resistance and most other production, type, and fitness traits were negligible.

A final alternative to selection for disease resistance would be to record all animals as either "healthy" or as "diseased", regardless of the specific disorders that they may or may not have experienced (e.g., Zwald et al., 2004). This approach might reduce the need for standardization of disease coding between farms and could reduce the number of covariance parameters to be estimated. Furthermore, it would lead to higher overall LIR, and this may decrease the chance of extreme category problems, in which observations in a particular subclass are all successes or all failures. However, such a simple approach would ignore potentially important differences in susceptibility or resistance to specific diseases, as well as differences in the economic value of these disorders.

\section{CONCLUSIONS}

In summary, the present study demonstrates the potential of multiple-trait analysis of farmer-recorded disease incidence traits as a tool for genetic selection for improved animal health. Significant genetic variation existed for all 6 health disorders examined herein. Heri-

Table 4. Product-moment correlations between PTA for probability of disease resistance and PTA for production, type, and other traits routinely evaluated by the USDA Animal Improvement Programs Laboratory (Beltsville, MD) and the Holstein Association USA (Brattleboro, VT).

\begin{tabular}{lrrrrr}
\hline & \multicolumn{5}{c}{ Probability of disease resistance } \\
\cline { 2 - 5 } PTA & $\begin{array}{l}\text { Metabolic } \\
\text { disorders }\end{array}$ & $\begin{array}{l}\text { Early lactation } \\
\text { disorders }\end{array}$ & $\begin{array}{l}\text { Reproductive } \\
\text { disorders }\end{array}$ & $\begin{array}{l}\text { All disorders } \\
\text { except mastitis }\end{array}$ & All disorders \\
\hline Milk & -0.12 & -0.03 & 0.03 & -0.06 & -0.09 \\
Fat \% & -0.15 & -0.03 & 0.00 & -0.01 & -0.02 \\
Protein \% & -0.08 & 0.01 & 0.01 & 0.02 & -0.04 \\
Somatic cell score & 0.01 & 0.02 & 0.03 & 0.00 & -0.14 \\
Productive life & 0.13 & 0.20 & 0.15 & 0.19 & 0.23 \\
Daughter pregnancy rate & 0.14 & 0.19 & 0.15 & 0.20 & 0.19 \\
Daughter calving ease & -0.02 & -0.05 & -0.04 & -0.03 & -0.02 \\
Stature & -0.06 & -0.06 & -0.04 & -0.05 & -0.05 \\
Strength & -0.07 & -0.04 & -0.01 & -0.04 & -0.07 \\
Body depth & -0.10 & -0.06 & -0.01 & -0.06 & -0.08 \\
Dairy form & -0.13 & -0.09 & -0.03 & -0.09 & -0.09 \\
Rump angle & -0.01 & 0.03 & 0.04 & 0.04 & 0.06 \\
Thurl width & -0.04 & -0.01 & 0.00 & -0.02 & -0.03 \\
Rear legs - side view & 0.01 & -0.02 & -0.04 & -0.02 & -0.10 \\
Rear legs - rear view & -0.05 & -0.09 & -0.06 & -0.08 & 0.00 \\
Foot angle & 0.02 & -0.04 & -0.05 & -0.03 & 0.03 \\
Fore udder attachment & -0.03 & 0.01 & 0.01 & -0.01 & -0.06 \\
Rear udder height & -0.14 & -0.03 & 0.06 & -0.04 & -0.05 \\
Rear udder width & -0.13 & 0.02 & 0.10 & 0.01 & 0.05 \\
Udder cleft & -0.07 & -0.03 & 0.01 & -0.03 & 0.09 \\
Udder depth & 0.03 & -0.01 & -0.04 & -0.02 & 0.04 \\
Front teat placement & -0.04 & 0.02 & 0.04 & 0.00 & -0.05 \\
Teat length & 0.01 & -0.03 & -0.03 & -0.03 & \\
\hline & & & & & \\
\hline
\end{tabular}


tability estimates for disease incidence rate in first lactation ranged from 0.04 to 0.14 , and estimated genetic correlations between health disorders ranged from -0.01 to 0.45 . Considerable effort is needed to improve the standardization of recording between farms, but due to the high market penetration of 3 software vendors (Dairy Records Management Systems, Raleigh, NC; DHI-Provo, Provo, UT; and Valley Ag Software, Tulare, CA) on large commercial dairies, the odds of achieving this goal are favorable.

Genetic correlations between individual disease incidences and disease composites with PL and DPR were generally favorable, indicating that PL and DPR improved as disease incidence decreased. However, corresponding relationships with body size and dairy form tended to be antagonistic, indicating that selection for body size and angularity may impair disease resistance. Favorable associations were also found between MAST and both SCS and udder conformation, indicating that selection for improved udders and lower SCS will tend to improve MAST resistance.

Genetic selection based on farmer-recorded disease traits could proceed in various ways. First, individual disease traits could be evaluated, published, and incorporated into an economic index. Although this approach is theoretically preferable, low incidence rates for certain diseases may lead to extreme category problems, and farmers may be faced with sire PTA for an overwhelming number of traits. Second, a multiple-trait model could be used to compute the probability of resistance to all diseases collectively, or the probability of resistance to certain groups of diseases, such as metabolic disorders or reproductive disorders. Such an approach may be appealing to end-users, and it may be more robust to variation in economic values of certain diseases on different farms.

Overall, many challenges exist with respect to data collection, data validation, statistical analysis, determination of economic values, and publication of results. However, trends toward rapid expansion of commercial dairies, greater reliance on herd management software programs, increased interest in health and fertility traits, and larger progeny group size among AI sires bode well for efforts toward development of genetic improvement programs for resistance to common health disorders in US dairy cattle.

\section{ACKNOWLEDGMENTS}

The authors gratefully acknowledge financial support for this project by Alta Genetics (Watertown, WI), and the USDA-ARS Animal Improvement Programs Laboratory (Beltsville, MD).

\section{REFERENCES}

Bartlett, P. C., P. K. Ngategize, J. B. Kaneene, J. H. Kirk, S. M. Anderson, and E. C. Mather. 1986. Cystic follicular disease in Michigan Holstein-Friesian cattle: Incidence, descriptive epidemiology, and economic impact. Prev. Vet. Med. 4:15-33.

Beaudeau, F., H. Seegers, V. Ducrocq, and C. Fourichon. 1999. Effect of health disorders on culling in dairy cows: A review and critical discussion. Proc. Intl. Wkshp. on EU Concerted Action on the Genetic Improvement of Functional Traits in Cattle. Interbull Bull. 21:139-151.

Chang, Y. M., D. Gianola, B. Heringstad, and G. Klemetsdal. 2004. Effects of trait definition on genetic parameter estimation in sire evaluation for clinical mastitis with threshold models. Anim. Sci. (accepted).

Dechow, C. D. 2003. Genetics of Body Condition Score. Ph.D. Diss., Dept. of Anim. Sci., Univ. of Tennessee, Knoxville.

Guard, C. 1998. Fresh cow problems are costly: Culling hurts the most. Proc. Ann. Conf. Vet. Med., Cornell Univ., Ithaca, NY.

Hansen, L. B., J. B. Cole, G. D. Marx, and A. J. Seykora. 1999. Productive life and reasons for disposal of Holstein cows selected for large versus small body size. J. Dairy Sci. 82:795-801.

Heringstad, B., R. Rekaya, D. Gianola, G. Klemetsdal, and K. A. Weigel. 2003. Genetic change for clinical mastitis in Norwegian cattle: A threshold model analysis. J. Dairy Sci. 86:369-375.

Jasper, D. E., J. S. McDonald, R. D. Mocherie, W. N. Philpo, R. J. Famswolth, and S. B. Spencer. 1982. Bovine mastitis research needs, funding, and sources of support. Page 184 in Proc. 21st Annu. Mtg. Natl. Mastitis Counc., Lexington, KY. Natl. Mastitis Counc., Madison, WI

Jones, W. P., L. B. Hansen, and H. Chester-Jones. 1994. Response of health care to selection for milk yield of dairy cattle. J. Dairy Sci. 77:3137-3152.

Pryce, J. E., and S. Brotherstone. 1999. Estimation of lifespan breeding values in the UK and their relationship with health and fertility traits. Proc. Intl. Wkshp. on EU Concerted Action on the Genetic Improvement of Functional Traits in Cattle. Interbull Bull. No. 21:166-169.

Rauw, W. M., E. Kanis, E. N. Noordhuizen-Stassen, and F. J. Grommers. 1998. Undesirable side effects of selection for high production efficiency in farm animals: A review. Livest. Prod. Sci. 56:15-33.

Rogers, G. W., G. Banos, and U. Sander-Nielsen. 1999. Genetic correlations among protein yield, productive life, and type traits from the United States and diseases other than mastitis from Denmark and Sweden. J. Dairy Sci. 82:1331-1338.

Rogers, G. W., G. L. Hargrove, T. J. Lawlor, Jr., and J. L. Ebersole. 1991. Correlations among linear type traits and somatic cell counts. J. Dairy Sci. 74:1087-1091.

Sander-Nielsen, U., G. A. Pedersen, J. Pedersen, and J. Jensen. 1999 Genetic variation in disease traits and their relationships with survival in Danish dairy cattle. Proc. Intl. Wkshp. on EU Concerted Action on the Genetic Improvement of Functional Traits in Cattle. Interbull Bull. No. 21:170-178.

Shaver, R. D. 1997. Nutritional risk factors in the etiology of left displaced abomasum in dairy cows: A review. J. Dairy Sci. 80:2249-2253.

Uribe, H. A., B. W. Kennedy, S. W. Martin, and D. F. Kelton. 1995. Genetic parameter estimates for common health disorders of Holstein cows. J. Dairy Sci. 78:421-430.

Zwald, N. R., K. A. Weigel, Y. M. Chang, R. D. Welper, and J. S. Clay. 2004. Genetic selection for health traits using producerrecorded data. I. Incidence rates, heritability estimates, and sire breeding values. J. Dairy Sci. 87:4287-4294. 